\title{
MEMBANGUN BUDAYA LITERASI DI SEKOLAH DASAR NEGERI TRANGSAN 02 GATAK KABUPATEN SUKOHARJO DALAM MENDUKUNG KEBERHASILAN KEGIATAN BELAJAR ABAD 21
}

\author{
Juminingsih \\ Guru SDN Trangsan 02 Gatak, Kabupaten Sukoharjo \\ e-mail:juminingsih77@gmail.com
}

\begin{abstract}
Primary school is one of the levels of education whose task is to realize the national education goals. In order to achieve this goal the school must have good quality. One effort to improve the quality of schools is to support facilities and infrastructure and improve the reading culture. This Best Practice is designed to support the work that the author has done as the principal. This study aims to describe the initial conditions of the school, explain the efforts, constraints and ways to overcome them in building a culture of literacy to support the success of teaching learning activities in explaining the results that have been achieved. The results showed that 1) The initial conditions of literacy were still low; 2) How to build a culture of literacy began with the procurement of facilities and infrastructure followed by habituation; 3) Constraints faced included facilitators, costs, and interests of students; 4) How to overcome existing problems namely with financial donations, attending workshops and holding tutoring and extracurricular activities; 5) The results achieved through the development of a literacy culture, namely the school can win several race champions. Suggestions are given that the government through the education office should be more focused on addressing issues related to literacy in primary schools and for principals to be role models in literacy.
\end{abstract}

Keywords: Literacy culture, school literacy movement.

\section{PENDAHULUAN}

Mencerdaskan kehidupan bangsa salah satu tujuan negara yang tertulis dalam pembukaan Undang-Undang Dasar 1945 mengamanatkan Pemerintah mengusahakan dan menyelenggarakan satu sistem pendidikan nasional. "Pendidikan nasional berfungsi mengembangkan kemampuan dan membentuk watak serta peradaban bangsa yang bermartabat dalam rangka mencerdaskan kehidupan bangsa, bertujuan untuk berkembangnya potensi peserta didik agar 
menjadi manusia yang beriman dan bertakwa kepada Tuhan Yang Maha Esa, berakhlak mulia, sehat, berilmu, cakap, kreatif, mandiri, dan menjadi warga negara yang demokratis serta bertanggungjawab (Undang-undang tentang sistim pendidikan nasional ). Sebagaimana tercantum dalam Undang-undang di atas fungsi dari pendidikan nasional mengembangankan manusia menjadi berilmu dan berkarakter. Jalur, jenjang, dan jenis pendidikan dapat diwujudkan dalam bentuk satuan pendidikan yang diselenggarakan oleh Pemerintah, Pemerintah Daerah, dan/ atau masyarakat.

Sekolah dasar merupakan salah satu tahap jenjang pendidikan nasional yang berfungsi mewujudkan tujuan tersebut. Untuk itu diperlukan kualitas sekolah yang baik. Kepala sekolah merupakan komponen vital dan penentu dalam peningkatan kualitas suatu sekolah.

Budaya adalah suatu yang meliputi pengetahuan, keyakinan, seni moral, adat istiadat serta kemampuan dan kebiasaan yang dimiliki individu sebagai bagian dari masyarakat (Hawkin, Best dan Coney dalam Simamora. 2000: 144). Literasi adalah kemampuan melek huruf dimana termasuk kemampuan membaca dan menulis. Kemampuan melek huruf disini tidak hanya merupakan kemampuan seseorang untuk mengenali membaca maupun menerjemahkan huruf dan angka saja tetapi juga kemampuan untuk memahami ide dalam gambar, video maupun adegan (Malawi. 2017:8).

Budaya literasi berawal dari kemampuan individu dalam membaca, menulis, dan mendambah kemampuan yang membuat seseorang mampu berfikir kritis, berkomunikasi efektif, mampu memecahkan masalah serta mengembankan potensinya dalam kehidupan. kemudian kemmpuan tersebut akan berubah menjadi kebiasaan sehingga tumbuh dalam pola kemampuan literasi antar individu satu dengan yang lain sehingga budaya literasi bukan hanya ketrampilan teknis membaca dan menulis individu saja tetapi sekelompok komunitas, warga sekolah maupun masyarakat.

Literasi sekolah adalah kemampuan mengakses, memahami dan menggunakan sesuatu secara cerdas melalui berbagai aktifitas. Aktifitas tersebut dapat berupa melihat, menyimak, membaca menulis, dan atau berbicara. (Fauziah: 2016:2) “Gerakan Literasi Sekolah (Gerakan Literasi Sekolah) merupakan gerakan literasi yang aktivitanya banyak dilakukan di sekolah dengan melibatkan peserta didik, pendidik dan tenaga kependidikan, serta orang tua." (Atmazaki, 2017: 19). Gerakan literasi sekolah dilaksanakan dengan mengintegrasikan antara kegiatan intra-kurikuler, ko-kurikuler dan ekstra-kurikuler. Menurut pengertian di atas gerakan literasi sekolah adalah praktik literasi yang dilaksanakan di lingkungan sekolah baik dalam kegiatan belajar mengajar (KBM) di kelas maupun di luar kelas, yang menunjang seperti penugasan, pekerjaan rumah, serta kegiatan di luar jam pelajaran

Gerakan Literasi Sekolah merupakan suatu gerakan me-literasikan semua warga yang berada di lingkup sekolah, baik kepala sekolah,guru,penjaga ,bahkan orang tua sehingga mereka memiliki peran vital sebagai role model dan suri tauladan dalam kegiatan berliterasi. Kegiatan ini diupayakan menjadi sebuah budaya yang tentu saja memerlukan dukungan dari beberapa pihak seperti pegiat literasi, orang tua,komite, tokoh masyarakan dan professional. "Gerakan Literasi Sekolah merupakan sebuah upaya yang dilakukan secara menyeluruh untuk 
menjadikan sekolah sebagai organisasi pembelajaran yang warganya literat sepanjang hayat melalui pelibatan public" (Fauziah, 2016: 2).

Kegiatan literasi tidak berhenti sampai anak bisa membaca dan minat untuk membaca sebagai hasil pembudayaan literasi. Literasi harus dikembangkan dalam pembelajaran guna membentuk karakter peserta didik dan melatih peserta didik untuk berfikir kritis. "Pengembangan kemampuan literasi di sekolah akan meningkatkan kemampuan belajar peserta didik" (Malawi, 2018: 201).

Dalam penerapannya kegiatan literasi sekolah dapat dilaksanakan dalam berbagai bentuk seperti, pembelajaran di kelas, pembiasaan, serta pemanfaatan sumber belajar. gerakan literasi lewat pembelajaran di kelas berupa materi yang di integrasikan dalam mata pelajaran, metode serta pengelolaan kelas. Kegiatan budaya sekolah dilaksanakan di luar pembelajaran. Hal ini dapat dilakukan melalui beberapa langkah contoh seperti upacara bendera, menyanyikan lagu nasional, menyanyikan lagu daerah, membaca 15 menit dan pembiasaan lain seperti penumbuhan budi pekerti. Pemanfaatan sumber belajar di masyarakat dapat dilakukan dengan memanfaatkan sumber daya yang ada seperti pasar, stasiun, profesi yang ada sebagai bahan pembelajaran.

Berdasarkan latar belakang masalah yaitu masih belum adanya budaya literasi di Sekolah Dasar Negeri Trangsan 02 untuk mendukung keberhasilan kegiatan belajar mengajar, penulis mengambil langkah pemecahan masalah dengan melakukan kegiatan berupa lima aspek strategi dalam usaha menumbuhkan budaya literasi (Atmazaki, 2017: 19). Kegiatan-kegiatan tersebut adalah: (1) Penguatan kapasitas fasilitator; (2) Peningkatan jumlah dan ragam sumber bacaan bermutu; (3) Perluasan akses terhadap sumber belajar dan cakupan peserta belajar; (4) Peningkatan pelibatan publik; (5) Penguatan tata kelola.

\section{METODE PENELITIAN}

Untuk membangun budaya literasi untuk mendukung keberhasilan Kegiatan Belajar Mengajar di Sekolah dasar negeri Trangsan 02 pada pembelajaran abad 21, penulis melakukan 4 langkah stategis, yaitu:

1. Mengobservasi dan menggali potensi yang belum bisa tumbuh dan belum bisa berkembang serta yang belum bisa di laksanankan dalam rangka membangun literasi di Sekolah Dasar Negeri Trangsan 02

2. Menyusun program kusus yaitu program literasi dalam rangka membangun budaya literasi di Sekolah Dasar Negeri Trangsan 02

3. Melaksanakan program literasi dengan memprioritaskan program yang bersifat urgen atau mendesak yang segera harus ditangani

4. Mengukur capaian kemampuan peserta didik dalam berliterasi menggunakan dokumentasi.

Instrumen yang digunakan dalam prosedur diatas antara lain; lembar observasi, wawancara dan dokumentasi.

\section{HASIL PENELITIAN DAN PEMBAHASAN}

\section{Gambaran Kondisi Awal Sekolah Dasar Negeri Trangsan 02}

Pada awal penulis bertugas sebagai Kepala Sekolah Dasar Negeri Trangsan 02, penulis mengamati dan melakukan orientasi sekolah untuk mengenal dan mendapatkan data konsisi sekolah. Penulis masuk ke Sekolah Dasar Negeri 
Trangsan 02 pada bulan April 2014 sebagai kepala sekolah. keberadaan Sekolah Dasar Negeri Trangsan 02 secara fisik, gedung terdiri dari 6 kelas, 1 kantor guru, 1 kantor Kepala Sekolah, 1 gedung perpustakaan yang belum berfungsi, rumah dinas rusak. keadaan pendidik dan tenaga kependidikan ada 4 guru PNS dan 4 guru WB. Kondisi anak, masingmasing kelas adalah variatif kemampuannya tetapi tiap kelas ada $25 \%$ yang kemampuannya terbatas atau kurang. Buku yang tesedia sangat terbatas. Buku belum memenuhi perbandingan yang seharusnya yaitu 1:1. Tidak ada buku cerita. Tidak ada poster. Tidak ada internet dan komite belum berjalan. Minat baca anak- anak belum tumbuh.

\section{Upaya Membangun Budaya Literasi di Sekolah}

Identifikasi masalah berdasarkan observasi kondisi awal Sekolah Dasar Negeri Trangsan 02 digunakan sebagai dasar untuk menentukan program dan upaya-upaya yang dapat dilakukan untuk mendorong keberhasilan Kegiatan Belajar Mengajar di Sekolah Dasar Negeri Trangsan 02 dengan fokus pada pembangunan budaya literasi. Kegiatan-kegiatan yang telah disusun dan dilaksanakan, dijabarkan sebagai berikut:

1. Penguatan Kapasitas Fasilitator

Fasilitator untuk gerakan literasi sekolah adalah guru, dan tenaga kependidikan. Guru harus mempunyai kemampuan literasi dan minat baca yang tinngi. Dengan kemampuan guru kuat akan mendorong peserta didiknya ikut mempunyai minat baca yang tinggi pula serta bisa mengelola kelas dan mengelola peserta didik dengan sarana buku-buku yang ada .Guru harus bisa menjadi contoh bagi peserta didik yang akhirya akan menunjang keberhasilan pembangunan budaya literasi.. Penguatan kapasitas fasilitator dilakukan dengan memberikan sosialisasi dan pengarahan kepada guru dan tenaga kependidikan dalam penerapan literasi baik melalui pembelajaran di kelas maupun pembelajaran di luar kelas.

2. Peningkatan Jumlah dan Ragam Sumber Bacaan Bermutu

Kepala sekolah berkewajiban meningkatkan jumlah dan ragam bacaan baik buku-buku pelajaran maupun non pelajaran. Penyediaan tidak terbatas pada buku pelajaran saja tetapi juga penyediaan alat peraga dam mainan adukatif. Ragam bahan literasi juga dengan menyediakan bahan belajar dalam bentuk digital. Ragam bahan literasi bisa juga dengan kegiatan menulis bagi peserta didik, seperti menulis karya ilmiah,menulis pantun, menulis kata mutiara, menulis poster.

3. Perluasan Akses terhadap Sumber Belajar dan Cakupan Peserta Belajar

Pengembangan sarana penunjang yang membentuk ekosistem kaya literasi dilakukan kepala sekolah dengan mengatur penyediaan pojok baca di setiap kelas, penyediaan pojok baca di mushola, penyediaan pojok baca untuk orang tua pengantar dan penjemput peserta didik, pojok baca untuk para anggota komite, pemasangan poster-poster di area sekolah yang strategis misalnya pemasangan poster di kantin, di tempat wudhu,di tempat parkir sepeda, penulisan nama pohon dan bahasa latin dari pohon yang ada di sekolah.

Melihat potensi sela ruang di tiap pojok kelas dan berdasar pada tahapan gerakan literasi sekolah yang telah dicanangkan pemerintah, penulis menggerakan jajaran guru untuk mengadakan pojok baca pada setiap kelas. Hal ini telah dirintis sejak tahun 2016 dan telah berlangsung hingga sekarang. 
Pengadaan ruang baca tidak hanya terbatas di dalam kelas ataupun di perpustakaan saja. Penulis juga mengatur pojok baca di mushola. pojok baca ini berisi kitab suci Al-quran, hadist serta djuz 'amma, kumpulan doa-doa,sejarahislam Untuk menanamkan karakter religious pada peserta didik, penulis sebagai kepala sekolah memprogramkan shalatdzuhur berjamaah. Shalat dzuhur berjamaah ini dilaksanakan oleh kepala sekoah, guru dan tenaga kependidikan serta peserta didik dari kelas IV hingga kelas VI. Setelah shalatdzuhur berjamaah, dzikir dan doa, diadakan pembacaan hadist secara bergilir.

Pembacaan hadist ini ditujukan untuk meningkatkan kemampuan literasi mereka di bidang keagamaan dan menambah pengetahuan agama. Hal ini dimaksudkan agar mereka tidak hanya menjadi peserta didik yang cerdas tetapi juga religius. Selain pengadaan tersebut, dari penulis juga mengadakan pojok baca untuk wali murid yang mengantar dan menjemput para putra-putrinya. Hal ini dimaksudkan untuk menumbuhkan minat baca pada orang tua/wali murid sehingga pembangunan budaya literasi di Sekolah Dasar Negeri Trangsan 02 dapat berhasil secara maksimal.

Pemasangan poster di setiap kelas dilakukan dengan memanfaatkan dinding dinding kosong di ruang kelas. Poster yang dipajang merupakan bahan kaya teks yang mendukung kegiatan belajar mengajar. Tidak hanya itu, poster lain yang berisi slogan yang yang memberikan semangat bagi para peserta didik juga dipajang di beberapa tempat di area Sekolah Dasar Negeri Trangsan 02. Poster tidak hanya dipasang di kelas saja melainkan diseluruh area sekolah seperti di kantin, tempat wudhu, tempat parkir sepeda.

Untuk melengkapi penyediaan lingkungan yang kaya akan sumber literasi yang dapat digunakan untuk menambah ilmu pengetahuan peserta didik, penulis melakukan langkah pemasangan label nama untuk setiap pohon di lingkungan sekolah. Label ini berisi nama umum dan nama latin.

Penulis melakukan reaktivasi perpustakaan atau mengaktifkan kembali perpustakaan sekolah. Pada awal penulis masuk ke Sekolah Dasar Negeri Trangsan 02 seperti yang penulis jelaskan sebelumnya bahwa terdapat gedung perpustakaan luasnya memadai. Akan tetapi, belum aktif penggunaannya. Perpustakaan tertutup dan digunakan untuk menyimpan barang-barang dan arsip lama. Melihat potensi ini, pada bulan Agustus 2016 penulis mengajak seluruh jajaran guru dan tenaga kependidikan untuk reaktivasi perpustakaan Sekolah Dasar Negeri Trangsan 02. Langkah pertama yang dilakukan adalah menata ulang tata ruang perpustakaan. Langkah kedua yaitu menyortir bahan bacaan yang tidak rusak, masih dapat digunakan. Langkah ketiga yaitu menyusun petugas pengelola perpustakaan untuk selanjutnya dapat ditugaskan untuk membuat program untuk perpustakaan dan mengelola perpustakaan agar perpustakaan dapat terus aktif.

Selanjutnya, dari langkah yang telah dilakukan tadi perpustakaan Sekolah Dasar Negeri Trangsan 02 sudah aktif, salah satunya dengan melaksanakan regulasi buku pegangan guru, regulasi pengadaan buku bacaan untuk pojok baca setiap kelas, mengadakan jadwal kunjungan wajib perpustakaan setiap kelas yang diintegrasikan dalam kegiatan belajar mengajar, menyediakan layanan baca dan pinjam setiap istirahat, menyediakan layanan pinjam untuk guru dan karyawan. 


\section{Peningkatan Pelibatan Publik}

Pelibatan publik dilaksanakan dengan ikut festival bulan bahasa yang dilaksanakan dengan berbagai lomba pada bulan Oktober sekaligus memperingati bulan bahasa dengan mengadakan lomba menulis pidato, menulis karya ilmiah. Pelibatan public juga dilaksanakan dengan ikut festifalgrebeg rotan. Peningkatan pelibatan publik dalam membangun literasi juga dilakukan dengan mendengarkan sosialisasi dari dinas kesehatan yang sudah terjadwal setiap setahun $2 \mathrm{x}$ bulan februari dan september untuk pemberian vitamin dan imunisasi, penanggulangan cacingan,kampanyerubella. Pelibatan publik juga dilakukan dengan pihak dunia usaha dan industri rotan dengan mengadakan kunjungan ke industri rotan yang di sana diajarkan jenis bahan rotan dan cara menganyam rotan hingga menjadi sebuah kerajian.

5. Penguatan Tata Kelola

Untuk penguatan tata kelola kepala sekolah membuat kebijakan dengan membaca 15 menit. Ini juga termasuk mendukung program Gerakan Literasi pemerintah. Untuk Sekolah Dasar Negeri Trangsan 02 penulis memprogramkan kegiatan tersebut di awal pembelajaran. Sebelum kegiatan 15 menit baca, peserta didik dipimpin berdoa dan membaca surat-surat pendek di djuz 'amma, pembacaan djuzamma ini disesuaikan dengan tingkat kelas yang mereka tempuh, misalnya, untuk peserta didik kelas 1 dikenalkan pembacaan surat An Nas, Al Ikhlas, dan Al Falaq. Setelah mereka hafal kemudian dilanjutkan dengan surat yang lain menurut urutan di juz amma, setelah itu baru dilanjutkan dengan menyanyikan lagu nasional, lagu daerah dan macapat kemudian ditutup dengan dengan membaca buku 15 menit.

Untuk peserta didik kelas I karena sebagian besar dari mereka belum memiliki kemampuan mengenal aksara, mereka mendengarkan pembacaan cerita dari guru. Pembacaan cerita ini dimaksudkan untuk memberikan mereka pengetahuan dan pembelajaran budi pekerti. Hal ini berlaku pula untuk peserta didik kelas II. Peserta didik mendengarkan cerita dari guru. Cerita yang disampaikan guru yang mampu memberikan pelajaran budi pekerti. Selain itu mereka juga dikenalkan dan diceritakan biografi singkat para pahlawan yang tentu saja bertujuan mengenalkan dan memberikan contoh sikap kepahlawanan yang dapat mereka teladani.

Penerapan program ini untuk kelas III-VI adalah peserta didik membaca sendiri buku buku yang telah disediakan di pojok baca. Ketika kegiatan ini berlangsung guru memberikan contoh dengan ikut membaca. Langkah lain yang diambil penulis dalam penguatan tata kelola yaitu pengalokasian anggaran. Sesuai dengan aturan pemerintah dimana $20 \%$ dana bos harus dialokasikan untuk membeli buku maka, penulis menerapkan untuk pengadaan buku, baik buku pelajaran maupun buku non pelajaran diantaranya adalah buku fiksi maupun non fiksi . Ada juga beberapa buku non pelajaran yang juga diadakan yang mendukung keberhasilan Kegiatan Belajar Mengajar di sekolah seperti buku ensiklopedi, buku kamus, buku cerdas olimpiade, buku ketrampilan, buku cerita islami, dan lain lain.

Pengelolaan tata kelola yang lain dilakukan terkait komite sekolah. Pada mulanya Komite Sekolah Dasar Negeri Trangsan 02 sudah terbentuk akan tetapi belum berkontribusi aktif kepada sekolah. Oleh karena itu, penulis memiliki inisiatif untuk merintis keaktifan komite sekolah. Hal ini diawali dengan mengadakan pertemuan dengan komite sekolah setiap bulan. Melalui pertemuan 
komite sekolah yang dilaksanakan, penulis mensosialisasikan gerakan literasi di sekolah demi meningkatkan budaya literasi dan kemampuan literasi kepada semua putra-putri Sekolah Dasar Negeri Trangsan 02.

Melalui komite sekolah sebagai jembatan antara sekolah dan wali murid, lambat laun wali murid mulai memberikan perannya dalam usaha membangun literasi di Sekolah Dasar Negeri Trangsan 02. Wali murid kelas 6 yang telah lulus memberikan sumbangan dana yang dialokasikan untuk pengembangan dan pengadaan sumber bacaan di perpustakaan.

\section{Kendala yang Dihadapi Dalam Upaya Membangun Budaya Literasi di Sekolah}

Dalam melaksanakan upaya-upaya untuk membangun budaya literasi di Sekolah Dasar Negeri Trangsan 02 penulis menemukan beberapa kendala. Kendala yang dihadapi yaitu dari pendanaan, sosialisasi masih massif, budaya menonton TV tinggi, rasa malas tinggi, terlena bermain hingga kecanduan game online. Alokasi dana $20 \%$ dari dana BOS hanya cukup untuk memenuhi kebutuhan pengadaan buku pegangan, itupun belum mecukupi perbandingan 1:1. Sehingga tiadak tersisa dana untuk pembelian sumber bacaan lain baik fiksi maupun non fiksi. Selain itu kurangnya dana juga menghambat pengadaan fasilitas lain seperti komputer dan internet untuk menunjang literasi digital.

Sosialisasi Gerakan Literasi Sekolah masih belum maksimal. Selama ini sosialisasi hanya melalui media cetak, dan workshop sekali dua kali tetapi bukan pelatihan kusus tentang literasi. Masih kurangnya sosialisasi kepada guru dari pemerintah tentang literasi secara jelas dan rinci membuat guru masih kebingungan dalam mengimplementasikan gerakan literasi di sekolah sehingga guru tidak memiliki bekal yang cukup untuk menerapkan literasi di kelas.

Kendala terkait peserta didik yaitu minat menonton TV tinggi, karena televisi banyak menawarkan hiburan tetapi kurang bermutu, anak-anak terlalu banyak bermain dan sulit melawan rasa malas. Di era sekarang televisi banyak menyuguhkan tontonan yang memberikan dampak buruk bagi perilaku anak-anak dan perkembangann anak-anak. Selain itu anak-anak masih menyukai bermain yang kurang edukatif. Bermain terkadang membuat mereka capek dan lupa waktu. Rasa malas yang timbul dalam diri mereka tidak mampu mereka lawan dan sering kali menjadi hambatan dalam menumbuhkan minat baca.

\section{Solusi yang Dilakukan Dalam Upaya Membangun Budaya Literasi di Sekolah Dasar Negeri Trangsan 02}

Dari kendala yang penulis temukan dalam membangun budaya literasi sekolah, solusi yang diambil yaitu :

a. Sumbangan dana dari wali murid kelas VI dialokasikan untuk pengadaan sumber bacaan di perpustakaan.

b. Mengikuti workshop mandiri tentang gerakan literasi sekolah.

c. Memberikan les di luar jam pelajaran dan menyelenggarakan kegiatan ekstrakulikuler pramuka pada hari jumat dan ekstrakulikuler menganyam rotan pada hari sabtu. 


\section{Hasil yang Telah Dicapai Melalui Pembangunan Budaya Literasi di Sekolah}

Setelah proses yang cukup panjang dan masih berlangsung hingga sekarang, ketelatenan, kegigihan, tekad dan semangat yang tinggi, beberapa hasil mulai nampak dalam pembangunan budaya literasi di Sekolah Dasar Negeri Trangsan 02 untuk mendorong keberhasilan Kegiatan Belajar Mengajar dalam pembelajaran abad 21. Hasil tersebut akan penulis uraikan dibawah ini:

a. Peserta didik kelas I-VI dari yang tidak bisa membaca menjadi bisa membaca, dari tidak bisa menyimak menjadi bisa menyimak, dari tidak bisa memahami bacaan menjadi bisa memahami bacaan.

b. Peserta didik menjadi memiliki minat baca dan dapat memahami bacaan serta dapat menceritakan kembali isi bacaan.

c. Sekolah Dasar Negeri Trangsan 02 meraih beberapa juara di bidang literasi seperti:

1) Juara 1 lomba MAPSI 2017 tingkat kecamatan kategori Penulisan Karya Ilmiah putra

2) Juara 3 lomba MAPSI 2017 tingkat kecamatan kategori Penulisan Karya Ilmiah putri

3) Juara 1 lomba MAPSI 2017 tingkat kecamatan kategori Cerita Islami putri

4) Juara 3 lomba MAPSI 2017 tingkat kecamatan kategori Cerita Islami putra

5) Juara 1 lomba MAPSI 2017 tingkat kecamatan kategori Kewirausahaan putra

6) Juara 1 lomba MAPSI 2018 tingkat kecamatan kategori Cerita Islami putra

7) Juara 3 lomba MAPSI 2018 tingkat kecamatan kategori Cerita Islami putri

8) Juara 3 lomba Sinopsis tingkat kecamatan kategori putra

\section{KESIMPULAN}

Membangun budaya literasi dalam mendukung keberhasilan kegiatan belajar mengajar adalah suatu pekerjaan yang tidak mudah, dan bukan suatu gerakan yang tercipta secara instan, tidak seperti membalikkan tangan, tetapi membangun budaya literasi sekolah membutuhkan waktu lama, bertahap, dan telaten. Membangun budaya literasi sekolah perlu penanganan serius dan kerja keras serta ketelatenan, kesabaran, dan keuletan juga didukung dengan kerjasama dari banyak pihak yang terkait. Keberhasilan membangun budaya literasi sekolah juga ditentukan oleh manajemen dan tata kelola yang bagus dari kepala sekolah dan didukung oleh kesadaran para peserta didik, pendidik dan tenaga kependidikan, orang tua serta komite dan juga masyarakat dalam berliterasi.

Membangun budaya literasi di era digital sangatlah penting, agar mampu bersaing, bertanding, dan bersanding dengan bangsa lain. Jika tidak mampu bersaing maka akan terlindas dan ketinggalan jaman. Keberhasilan dalam membangun budaya literasi akan menciptakan anak-anak yang literat, maju, kreatif, berpikir kritis, komunikatif sehingga akan menang dalam persaingan. 


\section{DAFTAR PUSTAKA}

Atmazaki, dkk. 2017. Panduan Gerakan Literasi Nasional. Jakarta: Dikdasmen Kemendikbud.

Fauziah, Dewi U. 2016. Panduan Gerakan Literasi Sekolah di Sekolah Dasar. Jakarta: Dirjen Kemendikbud.

Malawi, Ibadullah. 2017. Pembelajaran Literasi Berbasis Sastra Lokal. Magetan: CV AE Media Grafika.

Malawi, Ibadullah. 2018. Pembaharuan Pembelajaran di Sekolah Dasar. Magetan: CV AE Media Grafika.

Simamora, Bilson. 2000. Panduan Riset Perilaku Konsumen. Jakarta: PT Gramedia Pustaka Utama. 